\title{
黒鉛陰極スパッタイオンポンプの 超高真空下の動作*
}

赤石 憲也**. 久保田 雄輔** . 浅野 正裕 ${ }^{* *}$. 渡辺 伸二**

（受付1989年12月 4 日，掲載決定1990年 3 月 3 日）

Operation of a Sputter Ion Pump with Graphite Cathodes in Ultrahigh Vacuum

\author{
Kenya AKAISHI**, Yusuke KUBOTA**, \\ Masahiro ASANO** and Shinji WATANABE**
}

(National Institute for Fusion Science, Nagoya 464-01, Japan)

(Received December 4, 1989, Accepted March 3, 1990)

\section{1. はじめに}

超高真空排気系は主ポンプと支援ポンプとから構成さ れることが多い. 主ポンプで排気できない気体成分を支 援ポンプに受けもたせ，全体として排気速度の低下を補 い, 到達圧力の改善を図るためである. スパッタイオン ポンプ系では $\mathrm{Ti}+$ ザリメーションポンプが支援ポンプ として最もよく用いられている. 主ポンプと支援ポンプ とでは各々が役割を分担し，真空装置の放出ガスを選択 的に排気する。しかし各々のポンプに颃いて Ti の触媒 作用に基ずく気体の生成があり，全体としての系の実効 排気速度はこの放出ガスの分だけ低下する ${ }^{1)}$. 従ってス パッタイオンポンプ系の到達可能な圧力限界は通常 $1.3 \times 10^{-9} \mathrm{~Pa}$ のオーダである.

最近 $1.3 \times 10^{-9} \mathrm{~Pa}$ よりも $1 \sim 2$ 桁低い極高真空の必要 性がいわれてきている．この目的達成のためには技術的 には種々の解があるであろら。例えば支援ポンプを $\mathrm{Ti}$

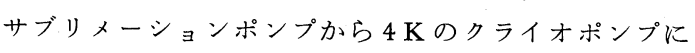
替えるのが一つの解となる2). また最近では真空装置の 材質をステンレス鋼からアルミ合金に替え, Tiサブリ メーションポンプを77 K に冷却することで, $1.3 \times 10^{-11}$ $\mathrm{Pa}$ の到達圧力が得られている3 ${ }^{3)}$. 本研究では超高真空

* 平成元年10月25日第30回真空に関する連合講演会で講演（25Aa-11）

** 核融合科学研究所 (
装置におけるベーキング後の残留ガスの主成分が水素で あることに注目し，水素を特によく排気でき，かつ反応 生成ガスの放出が無視できるよらな，支援ポンプとして のスパッタイオンポンプの可能性について考える.この ためにはTiに替える新しい陰極材料の選定が要るが, ここではその一つの候補として黒鉛に着目する.

黒鉛は核融合プラズマ実験装置のプラズマ対向材料と して最近使用されてきている．高融点材料であること， 金属や酸素などの不純物の含有が少ないことなどの特長 が黒鉛を採用する理由となっている，そしてプラズマ. 壁相互作用の観点から，黒鉛への水素トラッピング特 性, 水素イオン照射による物理および化学スパッタリン グ特性などが詳しく調べられてきている5). トラッピン グは真空で云うところの排気現象であるのに対して, 化 学スパッタリングは炭化水素ガスの放出現象である. 後 者はポンプのためには望ましくない現象である．ただし 化学スパッタリングは黒鉛が $200^{\circ} \mathrm{Cを}$ 越える高温に熱せ られるときはげしく起るが室温ではほとんど起きず，単 に物理スパッタリングだけとなる ${ }^{4,5)}$. 一方水素トラッ ピングでは飽和トラッピング数は入射イオンのエネルギ 一に依存して決まるが, 数 $\mathrm{KeV}$ の水素イオンの照射で は飽和トラッピング数は $10^{18} \mathrm{H} / \mathrm{cm}^{2}$ にも達する，黒鉛 を陰極とするスパッタイオンポンプをつくるとすると， 水素は陰極のイオン注入とトラッピングにより排気され 


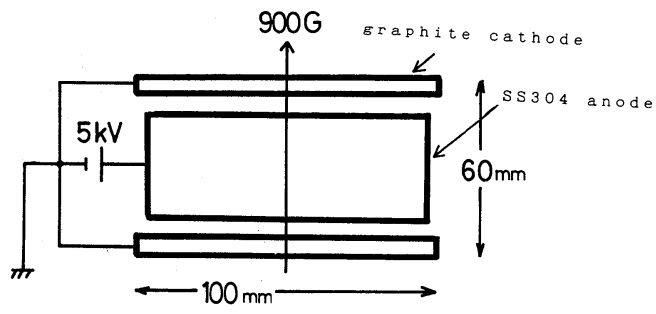

Fig. 1 A schematic drawing of a Penning cell.

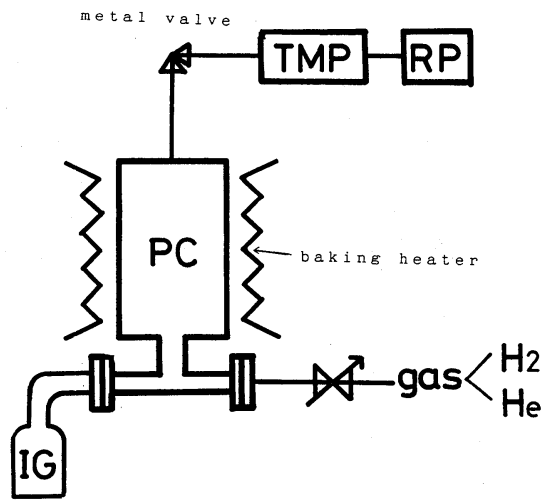

Fig. 2 A pumping system for operation test of a graphite ion pump. Here, PC: Penning cell, IG: BA type ionization gauge.

ることが期待される.トラップが飽和に達したとき，水 素の排気作用はなくなるが, $1.3 \times 10^{-8} \mathrm{~Pa}$ の圧力でのイ オンポンプの単位放電区間当りの放電電流が $0.1 \mathrm{nA}$ 以 下になることを考慮すれば， $10^{18} \mathrm{H} / \mathrm{cm}^{2}$ のトラップ数 に達するには長時間の放電の継続が要る.つまりこの支 援ポンプを超高真空下で動作する限り, 長時間水素排気 用ポンプとして機能することが期待できる.

本研究では黒鉛についての真空特性に関するデーター ベースを用い，上述した考え方に依り黒鉛陰極スパッタ イオンポンプを試作した．超高真空中で動作してみたの で，実験の概要と結果について報告する.

\section{2. 実験装置}

製作したイオンポンプの概略図を Fig. 1 に示す6). 陰 極は等方性黒鉛と呼ばれる ETP-10 (イビ電社)である. 寸法は厚さ $0.5 \mathrm{~cm}$, 長さ $10 \mathrm{~cm}$ ，幅 $4 \mathrm{~cm}$ である．陽極は 304 ステンレス鋼製であり，8区画のハニカム構造（1区 画は2.25 × $\left.1.9 \mathrm{~cm}^{2}\right)$ である. 印加磁場は900 gauss, 陽 極電圧は通常 $+5 \mathrm{kV}$ である. Fig. 2 にこのイオンポン プの動作テストのために用いた真空排気系の構成を略図

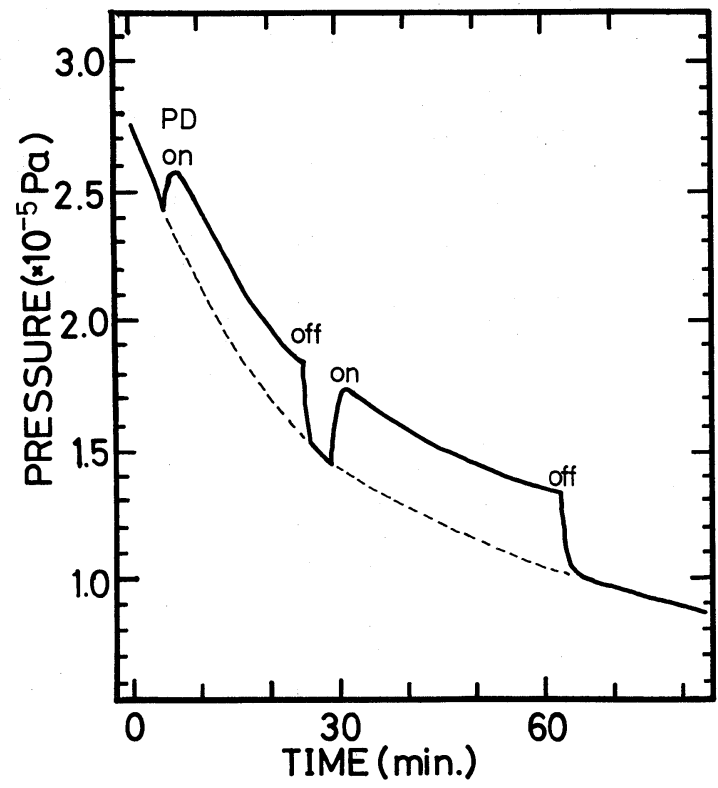

Fig. 3 A time evolution of total pressure in operation of the graphite ion pump at hydrogen gas admission. Here, DP: Penning discharge.

的に示す．イオンポンプのみを $250^{\circ} \mathrm{C} て ゙ 12$ 時間ベーキン グしたときのターボ分子ポンプ系の到達圧力は $4 \times 10^{-6}$ $\mathrm{Pa}$ である. 導入ガスとして水素とへリウムを用意した が，ヘリウムは陰極の放電洗浄用ガスであり，水素は排 気作用のチェックのために用いた.

\section{3. 放 電実験}

黒鉛陰極は1.33 Pa の水素ガス中で長期間ペニング放 電を続けたもの6)であるため，本研究ではイオン照射面 を新しくするために，この電極板をひっくり返してペニ ングセル内に取付けた。 ベーキング後 $6.6 \times 10^{-6} \mathrm{~Pa}$ の圧 力で, $5 \mathrm{kV}$ の放電を行ってみた。放電開始と共に圧力 バーストが頻繁に起り, 平均的な圧力上昇は $\Delta \mathrm{P}=8 \times$ $10^{-7} \mathrm{~Pa}$ であった，明らかに残留ガスのイオン衝撃のも とでは, 陰極表面からの吸着ガスの放出が存在し, 容易 には放出しきらないことが認められた。そこで陰極表面 の洗浄のために，へリウムガスを $4 \times 10^{-3} \mathrm{~Pa}$ をで導入 し $3 \mathrm{kV}$ の電圧で約 3 時間放電を行った.この前処理後 は圧力バーストは全く起こらない静かな放電可能となつ た。 その後 $10^{-6} \mathrm{~Pa}$ の圧力の水素雲囲気中で $5 \mathrm{kV}$ の放 電を試みた．Fig. 3 はその結果を示している．放電 on 状態で黒鉛陰極からのガス放出があり，ポンプとして機 能しないのがわかる．末だ陰極の放電洗浄が十分でない と考えて, 上述のへリウム放電洗浄を 3 時間程度行っ 


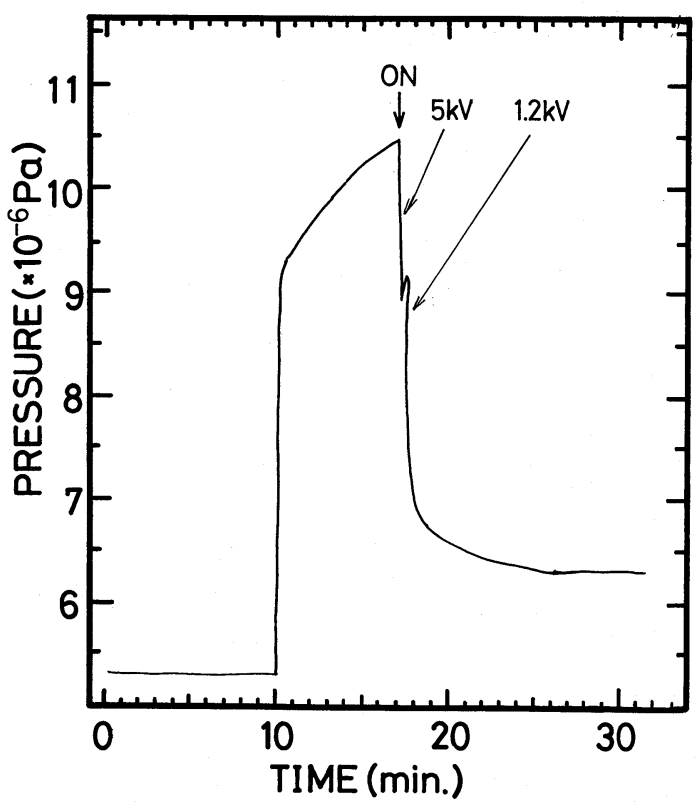

Fig. 4 A time evolution of total pressure in the Penning cell isolated from a turbomolecular pump.

た.この時放電パワー $(3 \mathrm{kV} \times 4 \mathrm{~mA}=12 \mathrm{~W})$ の陰極へ の入力により陰極の温度上昇は約 $100^{\circ} \mathrm{G}$ であった。

放電洗浄後再度イオンポンプを $4 \times 10^{-6} \mathrm{~Pa}$ の残留ガ ス下で起動してみた. しかし陽にはイオンポンプの排気 作用は観測されなかった。排気作用が認められない原因 が，ターボ分子ポンプとの併用排気のためではないか, と考えて分子ポンプに接続するメタルバルブをしぼり込 んでイオンポンプを起動してみた．バルブが閉じられる ことによりイオンポンプの付いた真空空間は放出ガスの ビルドアップにより上昇するが, ほぼ圧力上昇が飽和傾 向を示した. 時点で $5 \mathrm{kV}$ の放電を onにした. 結果を Fig. 4 に示す. 明らかにこの条件のもとでは圧力降下が 起り, 残留ガスに対する排気が観測された. しかも陽極
電纴を $5 \mathrm{kV}$ から低くしてゆくとき，図に示すように $1.2 \mathrm{kV}$ のとき $1 \times 10^{-5} \mathrm{~Pa}$ の最小到達圧力を得た.

\section{4. 考察とまとめ}

本研究では末だ予備的な実験結果しか得ていない．黒 鉛スパッタイオンポンプの性能を十分評価できる段階で はない、今後の系統的な実験研究への指針がわずかなが らであるが，示されたに過ぎない。

黒鉛の清浄化は重要であり，ポンプとしての機能を保 証するためには, ヘリウム放電洗浄は有効な手段となり 得るようである. 高いヘリウムガスの圧力のもとでの放 電では，放電パワーが陰極に投入されるので，へリウム の脱ガスのためにもこの放電条件は重要である.

$3 \mathrm{kV} \times 4 \mathrm{~mA}$ の放電パワーでは陰極は $100^{\circ} \mathrm{C}$ の温度に まで加熱された。しかし残留がス中での $5 \mathrm{kV}$ 放電にお いて，排気よりもガス放出を示すので，この程度の温度 で洗浄に用いたへリウムの陰極よりの脱ガスが十分行え たとは云い難い。

ターボ分子ポンプを切り離したときのイオンポンプの 排気試験では，系内の残留ガスが確かにイオンポンプに より排気される．この現象は残留ガス分析計による観測 によってより詳しく今後調べる必要がある．排気が始め て認められたことの原因としては，ターボ分子ポンプの 背圧側から逆拡散により高真空側に供給される水素やへ リウムの流れが断たれるためと思われる.

\section{[文献〕}

1) K. Terada, T. Okano and U. Tuzi: J. Vac. Sci. Technol A7 (1989) 2397.

2）赤石憲也：真空, 17 (1974) 90.

3) H. Ishimaru: J. Vac. Sci. Technol, A7 (1989) 2439.

4) R. Yamada, N. Nakamura, K. Sone and M. Saidoh: J. Nucl. Materials, 95 (1980) 278.

5）赤石憲也：核融合研究，55（1986） 329 .

6）浅野正裕, 渡辺伸二, 久保田雄輔, 赤石憲也 : 真空, 32 (1989) 394. 